Athens Journal of Mass Media and Communications

Volume 7, Issue 4, October 2021 - Pages 281-292

\title{
Ethiopian Media: Journalists Trends of Using Sources in Reporting Stories
}

\author{
By Mulatu Alemayehu Moges*
}

\begin{abstract}
Scholars in the field of media studies argued that journalists tend to choose the sources for their stories considering they are reliable, trustworthy, authoritative and able to articulate issues very well as well as accessibility of the sources to meet the deadline of reporting the stories (Gans, 2004; Cottle, 2006, 2009). However, the author of this article wants to insight a discussion on the relationship between journalists and sources in a country like Ethiopia, where the media are working under political pressures. To explore this issue, ten journalists and four editors/ editors-in-chief of selected newspapers, namely, Addis Admas, Reporter, The Ethiopian Herald and The Daily Monitor, were interviewed to get answers why they prefer to use certain sources when they need information to report cases such as conflicts in the country. The overall result of the qualitative data indicates that journalists self-censor in selecting sources to report, particularly, internal conflicts and other sensitive issues of the country. It is because they tend to use certain official sources as a mechanism of minimizing pressures and to be safe. Hence, the relationship between the sources and the journalists shall be discussed in line with journalists' selfcensorship trends, journalists' safety and the media situation in a country, which the scholars have not yet discussed.
\end{abstract}

Keywords: Ethiopian media, conflict, self-censorship, source, political pressure

\section{Introduction}

Ethiopia has been described as a media-unfriendly country for more than two decades. This is because the heavy control of state and its restriction on the media environment has largely denied journalists, especially the independent press, to access information and report stories independently (Moges, 2017b; Stremlau, 2011). Recent studies on media development in the country show that the media in general, and private press, in particular, are suffering from limited access to public information from government offices (IMS, 2018; Moges, 2020). More paradoxically, critical voices of the press have been restricted and pressurized either directly or indirectly (Moges, 2017b; Stremlau, 2011; Price et al., 2009). While independent journalists endeavored to report critical issues, they have been faced with prosecution, harassment and torture for a longer period (Doha Centre for Media Freedom, 2013; Reta, 2013; Stremlau, 2011; Price et al., 2009). This might be the reason that journalists massively self-censor when they report critical issues of the government due to fear of those pressures and harassment (Moges, 2017a; Moges, 2017b; Skjerdal, 2010). The political pressures have been commonly

\footnotetext{
*Assistant Professor, Addis Ababa University, Ethiopia.
} 
clearly seen in the media scenario in the country. Many private news outlets were shut down, their editors were arrested, and many journalists fled to second countries, those remaining were working under a climate of fear. As a result, the country has been labeled as one of the worst hubs of journalists in the world until 2018 (Freedom House, 2019).

However, CPJ recently released a report that indicates no journalists are reported to be in jail in the current day Ethiopia. ${ }^{1}$ This is wonderful news for those who aspire to ensure free press and freedom of expression in the country. The change has apparently happened in connection with the new political and economic reforms being carried out by the new leadership in the country. ${ }^{2}$ As a result of these changes, the country has recently improved its ranks from 150 to 110 in the world freedom index in 2019. ${ }^{3}$

Despite these changes, in the current democratic reform in the country, there are claims that journalists have recently been arrested and harassed in some parts. There are also claims that journalists are still self-censoring when they report issues in the media. Hence, it is fair to look at trends of self-censorship, and safety of journalists in using sources to report the stories related to conflicts and other politically sensitive issues in the country. This article thus tries to answer:

- How do the Ethiopian journalists select sources to report sensitive issues such as conflicts in the country?

- Why do they give priority to some group, particularly to government officials in reporting those issues which are critical of the state?

By raising these questions, the article wants to see the link between using sources and journalists in Ethiopia, which has not yet been studied.

\section{Literature Review}

\section{Relation between News Media and News Sources}

Ostensibly, media and sources attract each other. It is because one cannot survive without the other. For instance, the sources, particularly the politicians and business-oriented elites mostly want the media to get access and send their message to the public (Herman and Chomsky, 1988). This ultimately helps them send their views and promote themselves to the large audience. Since they have ardent interest in sending their message to the public, elite sources systematically approach the media and are mostly quoted in the stories (Herman and Chomsky, 1988). As a matter of fact, politicians are very prominent people; subsequently,

\footnotetext{
${ }^{1}$ CPJ (2019), Under Abiy, Ethiopia's media have more freedom but challenges remain. https:// cpj.org/blog/2019/04/ethiopia-abiy-ahmed-press-freedom-reform.php or https://qz.com/africa/ 1494561/ethiopia-has-no-jailed-journalists-in-2018-the-first-since-20 04/. [Accessed 22 June 2019]

${ }^{2}$ Abiy Ahmed (Ph.D.) came to power in March 2018 as a Prime Minister of Ethiopia.

${ }^{3}$ Reporters without Border (2019). www.rsf.org/en/randing.
} 
they easily draw the attention of the journalists as well as the large public.

Herman and Chomsky (1988) argue that sources mostly attempt to influence the journalists to send their agenda to the public through the media. Particularly, public relations and communication officers always intentionally find the gaps in the media to instantly send their messages by grabbing journalists' attention (Franklin and Carlson, 2011). This is a common tactic what the spin-doctors do. As a result, public views get less attention in the media.

On the other hand, journalists want the sources to get their job done. While journalists are writing their stories, they need to get accurate and timely information from their sources. Mostly, journalists quote the idea of the sources to get the reliability of the story as well as to maintain the credibility of the news. In fact, some scholars articulate that news can be news when it is said by sources or what prominent sources said (Zoch and Turk, 1999).

In a very precise manner, Gans states, "The source-journalist relationship is symbiotic, for while the sources need the journalists, the journalists also need the sources and therefore cannot afford to alienate them" (2003, p. 51). This mutual interdependence between the two is nothing except - the journalists looking for information to be reported and the sources desiring access to the public is to meet their goals (Franklin and Carlson, 2011, p. 2). It is like a give and take relationship: Journalists need materials and sources need to get attention.

However, in selecting the sources to be interviewed or quoted to report a story, there can be differences. "Who will be the sources of the story" is in question in many media firms. And the media follow different aspects to select the sources. For instance, a study in Netherlands indicates that among the five elements such as credibility, knowledge, willingness, timeliness, and sources relations that can help the journalists to select the sources during crisis, the journalists are mostly inclined to use the familiar sources (van der Meer et al., 2017). This means that the selection of the sources has certain differences according to the nature of the stories and the media situation.

While explaining the use of sources by journalists, Gans (2004) also mentioned six important points that can mostly be considered by the media. One of these is past "suitability" of the sources to the media. This can go either how his voice or narration is most suitable to the media. Taking this advantage, journalists always rush to that particular source when they want to write stories. The "productivity" of the sources is also the second reason. Some sources have the ability to provide valid and timely information. As a result of this, they become the target/focus of journalists when they need information immediately. Similarly, the "reliability" of the sources is also the other value that the journalists are drawn to the sources. The process of collecting relevant information is a hectic task to most of the journalists. In addition, getting timely and reliable information makes the process more difficult and complex. Hence, according to Gans (2004), getting reliable sources easily is a relief for journalists. In connection with reliability, getting "trustworthy" information is also another element that may lead journalists to approach some sources. As journalists are always in need of correct information from diverse sources, reliable and trustworthy sources minimize the challenges of the journalists in getting accurate and timely information. The other one is how the 
sources are "authoritative" (Gans, 2004, pp. 129-131). In fact, some other scholars also raised this concern. This is also reflected in the Ethiopian media. A study in 2006 indicated that journalists prefer to quote a source by taking how he/she is authoritative both in appointment and decision-making power (Dibaba, 2006). The journalists want to be heard, and they will get the audience if the story includes the voice of the authority. The last one is related to how the sources are "articulative" on a particular issue (Gans, 2004, p. 131).

There are scholars, for instance Wolfsfeld (2011), who argues that journalists are largely run after powerful sources. This is because the words of powerful politicians can usually be translated into power over the news media (Wolfsfeld, 2011, p. 09). Cottle on his behalf articulated that powerful persons or politicians are the dominant preference of the journalists. In his term, "Authority skew", Cottle (2006) and (2009) noted that journalists tend to quote military officials and political leaders in reporting serious cases, such as war and conflicts, of a country. His explanation is related to three points. The first one, the news value of the official sources is high and journalists prefer to source them. This can be related to the interests of the journalists to maximize the credibility of the news story. The second is related to meeting the deadline. While journalists are working under serious deadlines, they rush to gather the available information. And the third one is the most relevant information is available on the official sources (Cottle, 2006, 2009).

While the above mentioned scholars such as Gans (2004), Cottle (2006) and (2009) and Wolfsfeld (2011) have clearly articulated on journalists' ardent interests toward using official sources, they do not describe the other sides of their relation (sources and the media) by taking the context of the developing country, for instance Ethiopia, where the media situation is quite different from the west. This article argues that there are times that the journalists may consider some other issues that the scholars have not yet discussed in their literature. As the main interest of this article is to posit some points related to the Ethiopian media and its relations with sources, particularly officials in reporting political sensitive issues, such as conflict. To do so, it is fair to provide the Ethiopian media context. At this point, it is important to further look at the Ethiopian media, its situation, selfcensorship trend, and safety of the journalists, to see the context.

\section{Brief Description of Media Situations in Ethiopia}

While the introduction of the two media laws, the Press Proclamation in 1992 and later on, the Ethiopian constitution in 1995 led to significant changes in the media landscape in the country. Nevertheless, things could not go in the same path especially after the highly contested 2005 national elections, where at least 14 journalists and media owners along with 62 opposition party members and supporters were incarcerated in Ethiopia (Moges, 2017b; Doha Centre for Media Freedom, 2013; Stremlau, 2011). This led to the shutting down of critical publications thereby creating a significant setback on the media industry (Doha Centre for Media Freedom, 2013; Stremlau, 2011; Price et al., 2009). The 
crackdown also touched foreign journalists abroad and correspondents (including Swedish journalists) of foreign-based media. This put the state of press freedom in Ethiopia in the lowest ranking at the international index. ${ }^{4}$

As noted earlier, the media situation is recently promisingly progressing both in number and quality. ${ }^{5}$ However, the overall media situations have not been described as smooth as they should be. It has been common for a longer period that research on Ethiopian media has been finally come up with conclusions that indicate the Ethiopia media are working under serious pressures by the government (Reta, 2013). These situations put the Ethiopian journalists to work in a climate of fear. When they report a serious case, they know what kinds of measures the government can take. So, one can relate the sources and the journalists' relation in terms of the media situation in a given country.

The other most important point that the article wants to bring to the center for this discussion is the trends of self-censorship of journalists in the Ethiopian media. The author argues that the relationship between the sources and the journalists might be affected by the extent of self-censorship in the country. Articles and academic discussion indicate that it seems a trend in self-censoring themselves in Ethiopian media. For instance, Skjerdal (2010) underscored that the Ethiopian media, particularly the state owned extensively self-censor themselves in reporting stories. Moges (2017a) also argued that due to an immense pressure by the state, the Ethiopian journalists do not hesitate in refraining from reporting some critical issues of the government. As a result of such a trend, the author tends to describe the media of the country shifting from self-censorship to silence (Moges, 2017b). On his part, Skjerdal (2010) argued that the self-censorship trends of the Ethiopian journalism are a result of "relegation of ethical responsibility; elasticity of journalistic editing; confidence in critical audiences; and adherence to social responsibility" (p. 98). However, these points may not work at all issues, for instance, during conflict reporting.

The Ethiopian media laws are also mostly not creating a conductive working atmosphere to the journalists. For instance, Freedom of Mass Media and Access to Information (Proclamation No. 590/2008), and the Anti-Terrorism law (Proclamation No. 652/2009) can be mentioned as some of the draconian legal frames that limit the journalists' active participation in the media (IMS, 2018). The introduction of the Anti-Terrorism law in 2009 put freedom of expression in the worst state. Subsequent to the endorsement of the law, a number of prominent Ethiopian journalists, for instance, Eskinder Nega, Temesgen Desalegn and Riote Alemu (a courageous female journalist) were imprisoned under the law. Others were forced to leave the country fearing persecution. The rest of the journalists who do not move to the second country continue to live in extreme fear, which led them to self-censorship (Moges, 2017a). While this article has been written, the government of Ethiopia now embarks on enforcing to revise the media laws and others so as to be more workable for journalists. But, it is still fair to emphasize that journalists refrain from reporting serious cases, such as conflicts, or use the government officials as sources of the story.

\footnotetext{
${ }^{4}$ https://rsf.org/en/ethiopia.

${ }^{5}$ Ibid.
} 
It is also fair to look at how the safety of the journalists is ensured in the country. A close look at the Ethiopian media laws and policy, one cannot find a single article that deals with protecting the safety of journalists in the country. Being the case is sensitive, little is mentioned about the safety of journalists in Ethiopian laws and media working documents. For instance, not only the Ethiopian constitution (1995), which is considered liberal, but also the Proclamation of Freedom of the Media and access to Information (2008) do not state or put emphasis on the safety of the journalists. There are no articles that state about the fate of those journalists who are under certain danger. While there are quite many cases that affect the safety of journalists, there is no activity even to include some articles in the revised laws about journalists' safety in the country.

It is undeniable that the coming of Abiy Ahmed to power has relatively widened the media sphere. After a couple of months into power, Abiy freed journalists and political prisoners; people started accessing 260 previously blocked websites; the media, including the state broadcaster, started to broach subjects and include genuine public voices in their programs. However, the media freedom and the journalists' safety remain at a higher risk. In July 2018 two media outlets were forced out of the market for different reasons. Also, the crew of Diredawa Mass Media Agency was attacked while they were on the way to Addis Ababa to cover the visit of the Eritrean president, Isayais Afeworki. The safety of the journalists is highly important as many attack journalists with apparent impunity.

\section{Methods of the Study}

The nature of the study is purely exploratory. It mainly applied qualitative methods of data collection and analysis. As a tool, in-depth interviews were used to collect data from relevant key informants from the Ethiopian media. A total of fourteen journalists, editors and chief editors of four newspapers, namely Addis Admas, Reporter, The Daily Monitor and The Ethiopian Herald were included in the study. While the first three newspapers are privately owned, the fourth one is state owned. Addis Admas, a weekly and Reporter, a biweekly is published in Amharic Language, which is a working language of the federal government of Ethiopia. The Ethiopian Herald and The Daily Monitor, which are daily, are published in English language. All four newspapers can be described popular due to their relatively wider circulation and long-lived newspapers in the country.

The focuses of the interviews were mainly on the trend of conflicts' reporting in their newspapers. What kind of relationship between journalists and sources do they have? What are the driving forces the journalists to select sources to report sensitive issues? What are the main concerns or challenges in selecting the sources to report cases, particularly serious political and conflict issues in the country? These interview questions were prepared based on the research results of the previous studies. For instance, a study carried out earlier indicates that the majority of the sources of the conflict stories reported from 2006 to 2013 were found to be government sources (Moges, 2017b). Also, Reta (2013), Skjerdal (2012) indicated that government sources take the highest share to be quoted in the news stories of 
the Ethiopian media. Similarly, data collected from the selected newspapers from a period of 2006 to 2013 clearly showed that journalists do prefer to quote government officials dominantly. As this empirical data indicated the journalists tend to include the voice of the officials while reporting conflict issues in the country. It should be noted that reliance on government officials as sources is not particular to Ethiopia, but common in news media in other countries. Based on the results of the studies that mentioned above as an example, the author sets the interview questions to the working reporters and editors, and editors-in-chief. After getting consents from them, thorough interviews were carried out with them.

Reporters, editors and editor-in-chiefs are the key informants of this study. It is because they are the core of the newspapers in reporting stories and deciding on the contents of the newspapers. And it is believed that they would be the right experts to talk about how and why journalists mainly use government sources while reporting internal conflicts issues in Ethiopian newspapers.

Data collected through interviews from these key informants (from March 2014 to June 2014) were transcribed and summarized. Then, the data presented qualitatively and discussed thematically along with the scholar's ideas and previous studies.

\section{Data Presentation and Analysis}

Most key informants of the study indicated that they have their own criteria to pick the right sources of the information to write the stories. This can be, for instance, prominence of the sources, issues - sources relations (sources relevant to the issues), accessibility, and giving voice to all. An informant from the Addis Admas newspaper noted that she always gives attention to top political leaders in the country. It is because her interest is dealing with hot political issues of the country. Her argument is quoting somebody who is less prominent does not make her story more readable. Another informant from The Daily Monitor also indicated that he prefers to call government officials who are mostly available or ready to give information. It is all about the accessibility of the sources, which is one of the major challenges in the Ethiopian media. In such cases, the sources and journalists' relationship can be similar to what the scholars (for example, Gans, and Cottle) noted.

However, the journalists could not rely on those criteria when it comes to some critical issues of the country. For instance, the key informants of the study were asked about 'who are your preference sources of the stories while you are reporting sensitive issues, for instance conflicts and political controversies in the country'. Their answers are quite similar with the results of previous studies carried out in Ethiopian media. The informants say the government sources are more preferable to them to interview and collect information. However, their reasons are quite different from the previous studies that have been carried out not only in Ethiopia but also in other countries. It is also different from the scholars' ideas.

As a reason, one informant, for instance, noted that when the case is very 
sensitive, it is wise to approach the government sources. It is because the government sources have right information about the cases, and this helps the journalists to report the story more accurately. Similarly, another informant of the study also noted that since the cases are more related to crises, they do prefer to quote the police sources. It is because they are the responsible body of the case.

Another informant on the other hand raised the issues of timeliness. Since he is working in the newsroom of The Ethiopian Herald, he needs the information as soon as possible to be published. The story may lose its news value while the journalist searches for more inaccessible sources, which is also another challenge in Ethiopia (Moges, 2020). The journalists inclined to fetch information available in the government offices in reporting issues of conflicts and other sensitive cases. As noted in the data, the Ethiopian journalists tend to report the case immediately by using the government sources. This is because it is in the interest of the journalist to send the information to the audiences as soon as possible, though they are in a very critical time. There are scholars who describe how tough it is to report issues in a limited deadline from a "dangerous environment". Particularly, when journalists report about conflicts and war, they tend to use the government and army generals on both sides (the protagonist and antagonists) (Ibrahim et al., 2011; Cottle, 2006, 2009).

In addition to the above points the key informants mentioned most journalists tend to collect information from the top government officials, which they believe it is safe to quote them. According to the informants, ostensibly, the government seriously follows what is reported about conflict, and how it is reported about conflict in the local media. From the trend, the government reacts based on the extent and the way stories have been reported by the journalists. This might be a bad cause for harassment, intimidation, or prosecution of the journalists. An informant particularly noted that when it comes to serious conflict cases, most journalists are in dilemma between meeting the government interest (not to report the conflicts or reporting the case in line with the interest of the state) and meeting the public right to know (report it critically, then, the journalists may be harassed). What most journalists do, as the informant noted, they prefer to report the stories by quoting the government officials. In most cases, such stories may not be considered as neutral. However, journalists could be safe and free from a serious harassment and pressure from the state. It is because they collected the information from the government officials.

What makes it unique now, including the private press, which have been described as relatively critical of the government, have tended to be reserved themselves to report issues, including conflicts. This indicates that they are developing the wrong practice of journalism. As noted earlier, various studies on Ethiopian media indicated that journalists tend to collect information from top officials of the state while they are writing news stories. For instance, a study conducted on various issues in the country showed that government officials take the lion's share of the media coverage (Asegidew, 2013; Gusu, 2013; Reta, 2013; Skjerdal, 2012; Dibaba, 2006). A study on conflict reporting on Ethiopian media in 2017 also revealed similar results. More than two-thirds of the sources are from the top officials of the government (Moges, 2017b). 
To elaborate and discuss the reasons behind the strong interests of journalists to use government voices in Ethiopian media, the author wants to present four important points. These are the media laws, the media situations, self-censorship, and the level of protecting safety of journalists in the country. These four points at least can show how and why the journalists tend to rely on the government where the media work in critical time. In other terms, the journalists and the sources' relationships is determined by the extent of these points. These points are the center for the discussion next.

The journalists in the study mentioned one most important point that this article wants to put an emphasis. They noted that when there are political sensitive issues, they either report the cases by using government sources or disregard the issues. It is because when they use top officials to report the story, then, there is less probability of direct and indirect pressures from the government. Whereas, when they report cases by using other sources, though the story is true, there is a high chance of facing various pressures from the state and the security. So, the sources and the journalists' relationship are determined by the extent to which the media freedom prevails in the country. Since the journalists have been working in the climate of fear, they tend to use the government voice during conflict and crises. As a result of fear, the journalists tend to self-censor in a different way. While there may be many options to get the information from quite different and alternative sources, the journalists stick with using the government sources. If the journalists do not get the information from the government officials, then they surely do not report due to the fear of harassment. This is the other form of selfcensorship of journalists in Ethiopia.

The main reason for such poor reporting of the cases was the fear of the government that may put heavy pressures on the journalist after they report the stories. Key sources to this study stated that they do not have an ardent interest to report critical issues of the government during Meles and Hailemariam regimes. When they report those critical stories either they should come from the state themselves or the government should be quoted. As a result of this, large numbers of stories have included government voices. A previous study found that Ethiopian journalists were so hesitant to report internal conflicts in the country without the voice of government officials (Moges, 2017b). Key sources of the study noted that some journalists from the state and non-state-owned media in the country prefer not to report serious cases, such as conflicts, due to fear of political pressures and harassment from the government. Then, it seems to be a trend that the journalists do not want to report critical issues unless otherwise the government officials say it officially.

This study has identified some unique nature of the sources and the journalist relations in terms of the political, and media situations in the country. Firstly, the state may want to use the media and propagate its message dominantly, which could enhance the legitimacy of the power. This can be reflected that the government officials can systematically use the media largely to denounce the cases, conflict cases mostly, and major actors in the conflicts. This also helped the sources undermine the voice of the other sides (perceived as antagonists) (Moges, 2017b). Secondly, it can be argued that since the government is in charge of all 
responsibilities of the nations, there could be a high chance to be quoted by the media (Keeble, 2006; Gans, 2004). Thirdly, it is the fear of the journalists and they do self-censor while they are selecting the sources, which is not yet articulated by scholars.

The safety of the journalists is also another concern that should be looked at here when dealing with the sources and media relations in Ethiopia. As mentioned elsewhere above, even the laws do not support the media. For instance, there is no law that renders to protect the safety of the journalists in the country. This leads the journalists to work under the climate of fear.

In addition, research on media in the country shows that the media in Ethiopia are one of the weakest institutions that are bogged down with challenges from both within and outside media firms. The government has long been decried for stifling media freedom through restrictive laws that resulted in incarceration, exile of journalists, and closure of critical media. For instance, restrictive laws still exist in the country that put the journalists to work under a certain pressure. Anti-terrorism law can be mentioned as case. As informants noted that they do not know how the executive body can interpret a story by the laws, particularly anti-terrorism law, which may take a journalist to jail between ten to twenty years, if it is found guilty. This indicates that the laws do not create a conductive media environment that makes the journalist free to report the stories by incorporating diverse ideas from different sources.

\section{Conclusion}

Ethiopian journalists have been exercising their freedom of expression under several challenges. Some of them have faced serious harassments, arrests, and pressure while others are forced to leave the country. Ethiopia, being in the lowest rankings of press freedom indices for more than two decades in a row now, is a country where the safety of journalists has always been at risk. And, plenty of examples are available to make the case. This frustrates the journalists, particularly who work for the privately owned media, to report cases of conflicts. As a result of fear of pressures, local journalists dominantly safely use government sources as a mechanism of protecting their safety. Also, journalists showed high interests in selecting government sources by ignoring other relevant sources. This can be described that the Ethiopian journalists self-censor when they select sources of the story: it is not how the sources are relevant, rather it is how his/her position is and how it protects the journalists. It is one form of manifestation of self-censorship in the country. While Cottle (2006) and (2009), Gans (2004) and others listed out some other reasons mentioned in this article earlier, however, the Ethiopian journalists mostly relied on government sources as a mechanism of protecting themselves from pressures. Because there are no laws that protect the safety of journalists, they are either forced to be silent or use the government sources. Hence, high dependency of the journalists on the government voices can be looked at the prevailing freedom of the media in a country. This indicates that the relationship between the journalists and the sources in the context of Ethiopia 
media can be differently explained. The trends of self-censorship, the extent of pressures and the protection of journalists' safety shall be taken into account.

\section{References}

Asegidew, M. (2013). Media coverage of China-Africa relations: the case of the BBC and ETV. Unpublished MA Thesis. Addis Ababa, Ethiopia: Graduate School of Journalism and Communication, Addis Ababa University.

Cottle, S. (2006). Mediatized conflict: understanding media and conflicts in the contemporary world. Maidenhead, England: Open University Press.

Cottle, S. (2009). Global crisis reporting - Journalism in the global age. Maidenhead, England: Open University Press.

Dibaba, G. (2006). A study of source consideration and news selection in Ethiopia television. Unpublished MA Thesis. Addis Ababa, Ethiopia: School of Graduate Studies, Addis Ababa University.

Doha Centre for Media Freedom (2013). No home from home: the plight of East African exiled journalists Somalia, Ethiopia, Eritrea, Sudan and South Sudan. Doha: Doha Centre for Media Freedom.

Franklin, B., Carlson, M. (2011). Introduction. In B. Franklin, M. Carlson, Journalists, Sources, and Credibility: New Perspectives, 1-9. London, New York: Routledge.

Freedom House (2019). Freedom in the world 2019: democracy in retreat. Washington DC: Freedom House.

Gans, H. J. (2003). Democracy and the news. Oxford University Press.

Gans, H. J. (2004). Deciding what's news: a study of CBS evening news, NBC Nightly. Evanston, USA: Northwestern University Press.

Gusu, F. (2013). The framing of Sino-Ethiopia relation by Ethiopian newspapers: the case of the Ethiopian Herald and the reporter. Unpublished MA Thesis. Addis Ababa, Ethiopia: Addis Ababa University.

Herman, E. S., Chomsky, N. (1988). Manufacturing consent: the political economy of the mass media. New York, USA: Pantheon Books.

Ibrahim, F., Pawanteh, L., Kee, C. P., Basri, F. K., Hassan, B. R., Mahmud, W. A. (2011). Journalists and news sources: implications of professionalism in war reporting. The Innovation Journal: The Public Sector Innovation Journal, 16(3), 1-16.

International Media Support - IMS (2018). Media and freedom of expression assessment: Ethiopia in transition: hope amid challenges, Ethiopia. Copenhagen: International Media Support.

Keeble, R. (2006). Three newspapers handbook. $4^{\text {th }}$ Edition. London: Routledge.

Moges, A. M. (2017a). Ethiopian journalism from self-censoring to silence: a case of reporting on internal conflict. ESSACHESS - Journal for Communication Studies, 10(1), 111-128.

Moges, A. M. (2017b). Why Silence? Reporting internal conflict in Ethiopian. Doctoral Thesis. Oslo, Norway: Univerity of Oslo.

Moges, A. M. (2020). Assessment of media development in Ethiopia, based on UNESCO guidelines. A Study Report, Unpublished Document. Addis Ababa: Addis Ababa University and UNESCO.

Price, M., Marashi, I. I., Stremlau, N. (2009). Media in the peace-building process: Ethiopia and Iraq. Pennsylvania, USA: Annenberg School for Communication.

Reta, M. C. (2013). The quest for press freedom- One hundred years of history of the media in Ethiopia. New York, USA: University Press of America. 
Skjerdal, T. (2010). Justifying self-censorship - A perspective from Ethiopia. Westminster Papers in Communication and Culture, 2(7), 98-121.

Skjerdal, T. (2012). Competing loyalties: journalism culture in the Ethiopian state media. Ph.D. Dissertation. Oslo, Norway: University of Oslo.

Stremlau, N. (2011). The press and the political restructuring of Ethiopia. Journal of Eastern African Studies, 5(4), 716-732.

van der Meer, G. L. A. T., Verhoeven, P., Beentjes, W. J. J., Vliegenthart, R. (2017). Communication in times of crisis: the stakeholder relationship under pressure. Public Relation Review, 43(2), 426-440.

Wolfsfeld, G. (2011). Making sense of media and politics: five principles in political communication. New York and London: Routledge.

Zoch, L. M., Turk, J. V. (1999). Women making news: gender as a variable in source selection and use. Journalism and Mass Communication, 75(4), 762-775. 